\title{
FLEXURAL BEHAVIOUR OF LIGHT GAUGE COLD FORMED STEEL MEMBERS : COMPARISON OF IS CODE AND EURO CODE
}

\author{
A Jayaraman', S Athibaranan', A Mohanraj ${ }^{3}$ \\ ${ }^{1}$ Assistant Professor, Department of Civil Engineering, Bannari Amman Institute of Technology, Sathamangalam- \\ 638401, India, Tamilnadu \\ ${ }^{2}$ Assistant Professor, Department of Civil Engineering, Bannari Amman Institute of Technology, Sathamangalam- \\ 638401, India, Tamilnadu \\ ${ }^{3}$ Assistant Professor, Department of Civil Engineering, Bannari Amman Institute of Technology, Sathamangalam- \\ 638401, India, Tamilnadu
}

\begin{abstract}
Light - gauge steel evolved as a building material in the 1930's and reached large scale usage only after the Second World War. In comparison with conventional steel construction, where standard hot rolled shapes are used, the cold formed light gauge steel structures are relatively new development. This paper presents a study on behaviour and economical of cold formed steel (CFS) built up channel section using different codes. This paper provides an experimental investigation for the bending strength of Cold - Formed light gauge steel plain (stiffened) rectangular sections. The test specimens were brake pressed from high strength structural steel sheets. In addition, the test strengths were compared with the design strengths calculated using the Indian Standard and Euro codes Specification for Cold-Formed steel structures. Flexural members are linear members in which axial forces act to cause elongation (stretch). The theoretical data are calculated using Indian Standard code IS 801-1975 and the section properties of the specimens are obtained using IS 811-1975. The specimens are designed under uniformly distributed loading with simply supported condition. The research project aims to provide which code of practice given more economical, high bending strength, more load carrying capacity and high flexural strength. The studies reveal that the theoretical investigations limit state methods (SI method) have high bending strength, high load caring capacity, maximum deflection and minimum local buckling \& distortional buckling compare to the other codes.
\end{abstract}

Keywords: Cold formed steel, built up channel section, limit state method, working stress method, bending strength, deflection

\section{INTRODUCTION}

The light gauge steel members are defined structural members cold formed of shapes in cold -rolling machines or press brakes or bending brake operations from carbon or low - alloy steel sheets or strips or flats. The thickness of such members usually range from $0.378 \mathrm{~mm}$ to about $6.35 \mathrm{~mm}$, even though steel plates as thick as $25.4 \mathrm{~mm}$ may be cold formed into structural shapes. These thin steel sections are called cold formed as their manufacturing process of forming steel sections remains in a cold state these are also know as cold rolled steel sections against hot rolled steel sections. The light gauge steel members are formed in various shapes because of ease in their manufacture. The various shapes of cross sections are designed to use the material effectively and to simply and speed up construction operations. The cross section of the light gauge steel members varies with its application. The theoretical investigations of channel section have high bending strength, high load caring capacity, minimum deflection and minimum local buckling \& distortional buckling compare to the built up channel section by same cross sectional area. The numerical investigation of channel section is the maximum bending moment, torsional moment and deformation is higher than the built up channel section by same cross sectional area. But theoretical investigations are accuracy result ${ }^{(1)}$. T he steel sheets or strips used for light gauge steel members conform to IS: 1079- 1973 is 232 $\mathrm{N} / \mathrm{mm}^{2}$ and the ultimate strength is $390 \mathrm{~N} / \mathrm{mm}^{2}$. Factor Design (L.R.F.D.) methods has been successfully applied to the design of hot-rolled steel sections and cold - Formed steel members in the United States and other countries. L.R.F.D. method is used for the design of Cold - Formed steel structural members and connections. The design of Cold - Formed steel section is done by using I.S. 801-1975. This results in uneconomic design because in W.S.M. full section is not utilized. So to utilize the full cross - section of the section and to maintain economy, it is required to revise Indian Standard Code and also in S.I. System ${ }^{(2)}$. the Direct Strength method provides the best test-to-predicted ratio for both slender and unslender specimens. The test results demonstrate that many improvements in the elastic buckling and effective width calculation of $\mathrm{Cs}$ and Zs are still possible. The authors intend to pursue additional testing and analysis to determine the distortional buckling capacity of $\mathrm{Cs}$ and $\mathrm{Zs}$ as well as more closely define the role of fasteners and other details Light gauge steel sections are also known as cold formed steel sections. The thickness of the sheet used is generally between $1 \mathrm{~mm}$ and $8 \mathrm{~mm}$. These 
types of sections are extensively used in the building industry, as purlins girts, light struts roof sheeting, and floor decking. These sections become economical for light loads and to form useful surfaces such as roof covering, wall panels. Load carrying capacity should decreases with increase in Length and Width to thickness (W/t) ratio. Due to minimum thickness of cold rolled steel, considering the Local, torsional \& distortional buckling characteristics for its behaviour study most of the failures occurs at $1 / 3$ distance for $1,1.2 \mathrm{~mm}$ elements $\&$ at centre for $1.6,2 \mathrm{~mm}$ elements. The experimental investigation $2 \mathrm{~mm}$ thick cold formed steel "Long column with Web Stiffened" is preferable for "C Section" ${ }^{3}$ "These sections are manufactured primarily by two processes. Cold rolling is used to produce more number of sections having longer length whereas press breaking is used to produce a small number of sections having shorter length. As the thickness of the light gauge section increases the variation in increase of joint strength reduces for various thicknesses of Stiffener/packing plates. For $1.2 \mathrm{~mm}$ thick channel section it is observed that all failures are due to rupture with 3 bolts connection, and also for $1.5 \mathrm{~mm}$ thick channel section up to

\subsection{Types of Cold-Formed Steel Sections}

Typical forms of sections for cold formed structural members
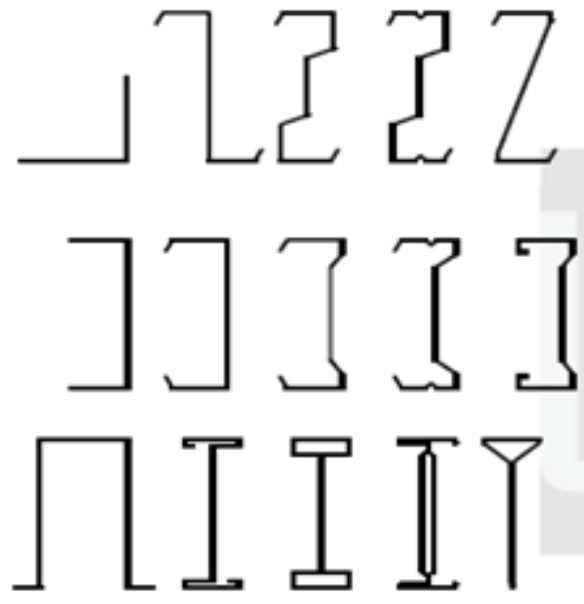

Single open sections

Profiled sheets and linear trays sections
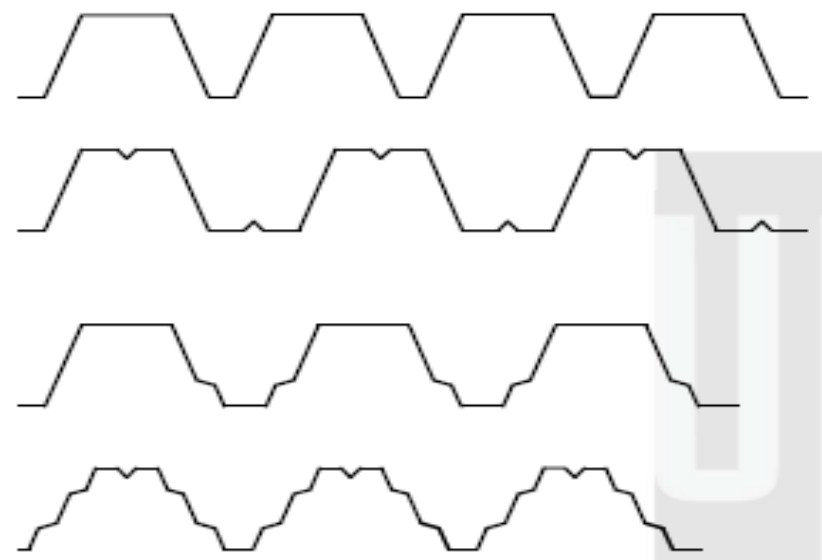

$3 \mathrm{~mm}$ thick Stiffener/Packing plate failure are due to rupture and for $4 \mathrm{~mm}$ thick Stiffener/packing plate the failure is due to vertical shear failure along the line of vertical connection. With use of $5 \mathrm{~mm}$ thick Stiffener/packing plates the failure is due to block shear failure ${ }^{(4)}$. Various types of section may be manufactured using light gauge steel. They includes angles, channel with and without lips, hat section lipped $\mathrm{Z}$ Section etc.. Cold Formed steel product such as Z-purlin has been commonly used in metal building industry more than 40 year in unites state due to their wide range of application, economy, ease of fabrication and high strengthto-weight ratios. Z- Purlins are predominantly used in light load and medium span situations such as roof systems ${ }^{(5)}$. Channels may be used as compression or flexural members. Hat section and $\mathrm{Z}$ section are used as flexural members. Hollow rectangular section used for variety of sections. Built up I section using Light gauge steel with lower $\mathrm{H} / \mathrm{t}$ aspect ratio behaves significantly showing elastic and plastic deformation both. With increment in $\mathrm{H} / \mathrm{t}$ aspect ratio this behaviour changes and shows failure in elastic zone ${ }^{(6)}$.
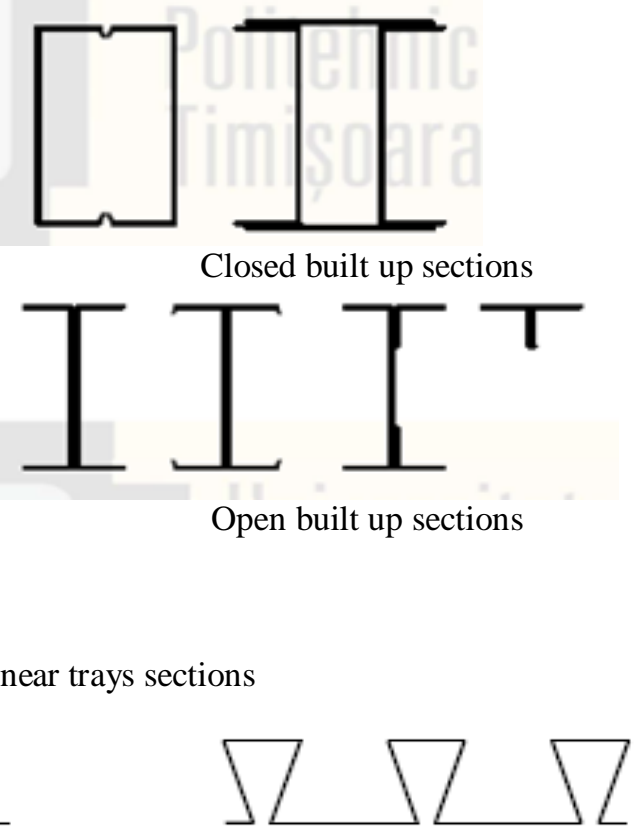

Closed built up sections
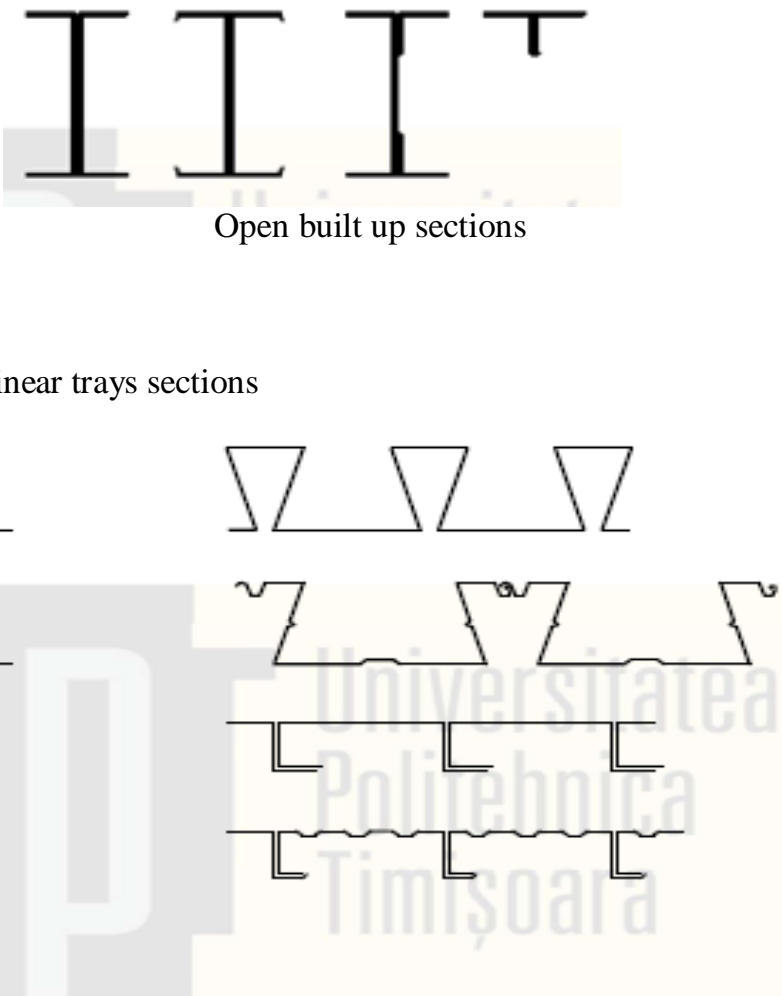
Advantages in Building Constructions

$\checkmark$ As compared with thicker hot-rolled shapes, cold-formed light members can be manufactured for relatively light loads and/or short spans;

$\checkmark$ Unusual sectional configurations can be produced economically by cold forming operations, and consequently favorable strength-to-weight ratios can be obtained;

$\checkmark \quad$ Nest able sections can be produced, allowing for compact packaging and shipping;

$\checkmark \quad$ Load carrying panel and decks can provide useful surface for floor, roof, and wall construction, and in other cases they can also provide enclosed cells for electrical and other conduits;

$\checkmark \quad$ Load-carrying panels and decks not only withstand loads normal to their surfaces, but they can also act as shear diaphragms to resist force in their own panels if they are adequately interconnected to each other and to supporting members.

\subsection{Advantages of using Cold-Formed Steel}

\section{Sections}

$\checkmark \quad$ Lightness;

$\checkmark \quad$ High strength and stiffness;

$\checkmark \quad$ Ability to provide long spans;

$\checkmark \quad$ Easy prefabrication and mass production;

$\checkmark \quad$ Fast and easy erection and installation;

$\checkmark \quad$ Substantial elimination of delay due to the weather;

$\checkmark$ Non-shrinking and non- creeping at ambient temperatures;

$\checkmark \quad$ Form work unneeded;

$\checkmark \quad$ Termite- proof and rat- proof;

$\checkmark \quad$ Uniform quality;

$\checkmark \quad$ Economy in transportation and handling;

$\checkmark \quad$ Non combustibility;

$\checkmark \quad$ Recyclable material.

\section{AIM OF THE STUDY}

The main aim of the study provides which code of practice is most economical, high bending strength, more load carrying capacity and high flexural strength by analysis of theoretical investigation.

\section{EXPERIMENTAL INVESTIGATION}

\subsection{Materials}

3.1.1 Light gauge steel physical properties: The rolled steel sheet is used. The physical properties of light gauge steel section given in Table 1.The properties taken from the Indian Standard code IS 800-2007

Table 1 Physical properties light gauge steel section

\begin{tabular}{|l|l|}
\hline Density of steel ( e ) & $7850 \mathrm{~kg} / \mathrm{m}^{3}$ \\
\hline Modulus of elasticity ,E & $2 \times 10^{5} \mathrm{~N} / \mathrm{mm}^{2}$ \\
\hline Poisson ratio & 0.3 \\
\hline Modulus of rigidity, G & $0.769 \times 10^{5} \mathrm{~N} / \mathrm{mm}^{2}$ \\
\hline
\end{tabular}

\begin{tabular}{|ll|l|l|}
\hline $\begin{array}{l}\text { CO efficient of thermal } \\
\text { expansion }(\alpha)\end{array}$ & $12 \times 10^{-6}$ \\
\hline
\end{tabular}

3.1.2 Light gauge steel physical properties: The rolled steel sheet is used. The physical properties of light gauge steel section given in Table 2.The properties taken from the euro code

Table 2. Physical properties light gauge steel section

\begin{tabular}{|l|l|}
\hline Yield strength & $350 \mathrm{~N} / \mathrm{mm}^{2}$ \\
\hline Modulus of elasticity ,E & $2.1 \times 10^{5} \mathrm{~N} / \mathrm{mm}^{2}$ \\
\hline Poisson ratio & 0.3 \\
\hline Modulus of rigidity, G & $0.769 \times 10^{5} \mathrm{~N} / \mathrm{mm}^{2}$ \\
\hline $\begin{array}{l}\mathrm{CO} \text { efficient of thermal } \\
\text { expansion }(\alpha)\end{array}$ & $12 \times 10^{-6}$ \\
\hline
\end{tabular}

3.1.2 Light gauge steel built up channel section properties: The rolled steel sheet is used. The built up channel sectional properties of light gauge steel section (given in Table 3) the properties taken from the Indian Standard code IS 811-2007

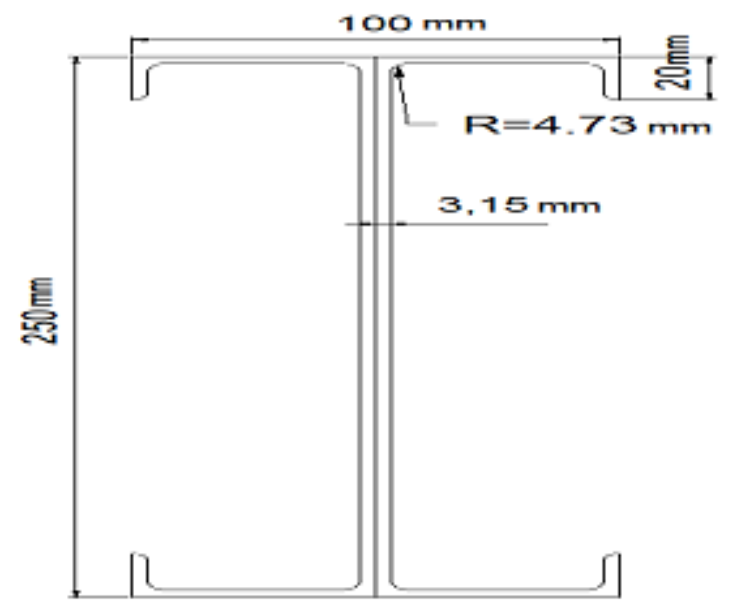

Table 3 Properties of light gauge steel built up Channel section

\begin{tabular}{|l|l|}
\hline Area & $2280 \mathrm{~mm}^{2}$ \\
\hline Elastic Section modulus & $74.1 \times 10^{3}$ \\
\hline $\begin{array}{l}\text { Moment of inertia of section } \\
\text { xx direction (Ixx) }\end{array}$ & $18.5 \times 10^{6} \mathrm{~mm}^{4}$ \\
\hline $\begin{array}{l}\text { Moment of inertia of section } \\
\text { yy direction (Iyy) }\end{array}$ & $916 \times 10^{6}$ \\
\hline Radius of gyration (rx) & $90 \mathrm{~mm}$ \\
\hline Radius of gyration (ry) & $16.5 \mathrm{~mm}$ \\
\hline
\end{tabular}

3.2 Theoretical Investigations of Built Up Channel Section $(250 \mathrm{~mm} \times 100 \mathrm{~mm} \times 6.30 \mathrm{~mm})$ using SI Method (Limit State Method)

3.2.1 Slenderness ratio $(\lambda)$ : The Slenderness ratio value is given in table 4

$$
\begin{aligned}
& \text { Slenderness ratio }(\lambda) \\
& \quad=\frac{\text { Effectivelengt } h}{\text { Radiousofgyration }(\text { rmin })}
\end{aligned}
$$


Table 4. Slenderness ratio

\begin{tabular}{|c|c|}
\hline Effectivelength $(\mathrm{mm})$ & Slenderness ratio $(\lambda)$ \\
\hline 1000 & 60.60 \\
\hline 2000 & 121.21 \\
\hline 3000 & 181.81 \\
\hline 4000 & 242.42 \\
\hline 5000 & 303.03 \\
\hline
\end{tabular}

The slenderness ratio for flexural member as per IS Code provide $300 \mathrm{~mm}$ for compression flange of a beam against lateral torsional buckling, so in this built up channel section ( $250 \mathrm{~mm} \times 100 \mathrm{~mm} \times 6.30 \mathrm{~mm}) \mathrm{mm}$ using construction up to $5 \mathrm{~m}$ only SI Method (limit state method) and IS method (working stress method)

3.2.2 Bending Moment (BM) of channel section ( $250 \mathrm{~mm}$ x 100mm x6.30mm) Maximum Bending Moment $=0.6$ $x$ fy $x Z_{x x}$

fy $=$ yield stress in cold form steel

$$
\mathrm{M}=10.4 \mathrm{KNm}
$$

$\mathrm{Z}_{\mathrm{xx}}$ = section modulus channel section

\subsubsection{Load caring capacity (p) of channel section} (250mm x 100mm x6.30mm) Bending Moment $=\frac{\mathrm{w} l^{2}}{8}$

$$
\operatorname{Maximum} \operatorname{Load}(\mathrm{p})=125.37 \mathrm{kN} / \mathrm{m}
$$

3.2.4 Moment of resistance of channel section $(250 \mathrm{~mm} x$ $100 \mathrm{~mm} \times 6.30 \mathrm{~mm}) \quad$ Moment of resistance $(\mathrm{MR})=\mathrm{Fb}$ $\mathrm{x}$ Zxx

$\frac{2}{3} f y-\frac{\mathrm{fy}^{2}}{5.4 \times \pi^{2} \times E x c b}($

$$
\mathrm{Fb}=
$$

Moment of resistance $(\mathrm{MR})=16.03 \times 10^{6} \mathrm{Nmm}$

$\mathrm{Fb}=$ basic design stress

$\mathrm{E}=$ young's modulus of steel

$\mathrm{Cb}=$ bending coefficient

\subsubsection{Shear capacity of channel section $(250 \mathrm{~mm} x$}
$100 \mathrm{~mm} \times 6.30 \mathrm{~mm}$ )
Maximum shear $=\frac{W l}{2}$

$=62.68 \mathrm{kN} / \mathrm{m}$

Maximum average shear stress $=\frac{V}{2 b d}=39.8 \mathrm{~N} / \mathrm{mm}^{2}$

\subsubsection{Allowable stresses in web of beam}

Shear stresses in webs - The maximum average shear stresses (Fv), on the gross area of a flat web shall not exceed (0.4 x fy)

$\mathrm{mm}^{2}$

$$
\begin{aligned}
& \text { For } \frac{h}{t}<\frac{1425}{\sqrt{ } f y} \\
& \mathrm{FV}=\frac{396 \sqrt{f y}}{\frac{h}{t}}=77.82 \mathrm{~N} /
\end{aligned}
$$

$$
\begin{aligned}
\frac{h}{t} & =78 \\
\frac{1425}{\sqrt{f y}} & =92.95 \\
\mathrm{FV} & =77.82 \mathrm{~N} / \mathrm{mm}^{2}>10.42
\end{aligned}
$$

$\mathrm{N} / \mathrm{mm}^{2}$ Hence Safe in shear
3.2.7 Combined bending and shear stress in webs: $f b^{\prime} w^{\prime}=$ $0.6 f y\left[\frac{\mathrm{y}-\mathrm{t}}{t}\right]=4335 \mathrm{~N} / \mathrm{mm}^{2}$

3.2.8 Bending and shear stress in webs: $f b w=\frac{3525000}{\left(\frac{h}{t}\right) 2}=$ $579.39 \mathrm{~N} / \mathrm{mm}^{2}$.

$$
4355 \mathrm{~N} / \mathrm{mm}^{2}>133.6 \mathrm{~N} / \mathrm{mm}^{2} \text {. Hence safe }
$$

in bending stress

\subsubsection{Check for deflection of channel section $(250 \mathrm{~mm} x$} $100 \mathrm{~mm} \times 6.30 \mathrm{~mm})$

The actual deflection $(\Delta)$ and Permissible deflection is given in table 5 .

$$
\begin{aligned}
& \text { Actual deflection }(\Delta)=\frac{5 W l^{4}}{384 E_{\text {span }}} \\
& \text { Permissible deflection }=\frac{\text { S25 }}{32}
\end{aligned}
$$

Table 5. Deflection

\begin{tabular}{|c|c|c|}
\hline $\begin{array}{l}\text { Effectivelength } \\
(\mathrm{mm})\end{array}$ & $\begin{array}{l}\text { Actual } \\
\text { Deflectio } \\
\mathrm{n}(\Delta) \\
(\mathrm{mm})\end{array}$ & $\begin{array}{l}\text { Permissibl } \\
\mathrm{e} \\
\text { deflection } \\
(\Delta)(\mathrm{mm})\end{array}$ \\
\hline 1000 & 0.44 & 3.07 \\
\hline 2000 & 7.05 & 6.15 \\
\hline 3000 & 35.72 & 9.230 \\
\hline 4000 & 112.94 & 12.30 \\
\hline 5000 & 275.68 & 15.38 \\
\hline
\end{tabular}

\subsection{Theoretical Investigations of Built Up Channel} Section $(250 \mathrm{~mm} \times 100 \mathrm{~mm} \times 6.30 \mathrm{~mm})$ using IS Method (Woking Stress Method)

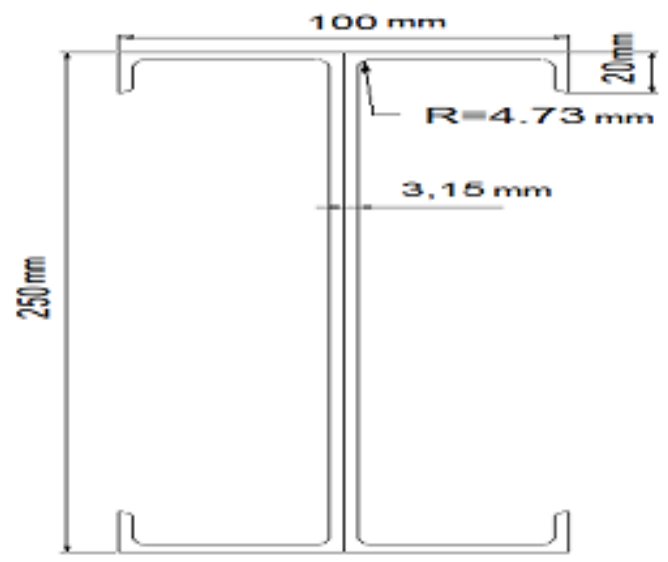

3.3.1 Bending Moment (BM) of built up channel section ( $250 \mathrm{~mm} \times 100 \mathrm{~mm} \times 6.30 \mathrm{~mm})$

Maximum Bending Moment $=0.6 \mathrm{x}$ fy $\mathrm{x} \mathrm{Z}_{\mathrm{xx}}$

$$
\mathrm{M}=10.4 \mathrm{KNm}
$$

3.3.2 Load caring capacity (p) of channel section ( $250 \mathrm{~mm} \times 100 \mathrm{~mm} \times 6.30 \mathrm{~mm})$

$$
\text { Bending Moment }=\frac{\mathrm{w} l^{2}}{8}
$$

Maximum $\operatorname{Load}(\mathrm{p})=83.58 \mathrm{kN} / \mathrm{m}$ 
3.3.3 Moment of resistance of channel section $(250 \mathrm{~mm} x$ $100 \mathrm{~mm} \times 6.30 \mathrm{~mm}$ )

Moment of resistance $(\mathrm{MR})=\mathrm{Fb} \times \mathrm{Zxx}$

$$
\begin{aligned}
\frac{2}{3} f y-\frac{\mathrm{fy}^{2}}{5.4 \times \pi^{2} \times E \times c b}(A) & \\
\mathrm{Fb} & =154.16 \mathrm{~N} / \mathrm{mm}^{2} \\
\text { Moment of resistance }(\mathrm{MR}) & =10.4 \times 10^{6} \mathrm{Nmm}
\end{aligned}
$$$$
\mathrm{Fb}=
$$

\subsubsection{Shear capacity of channel section $(250 \mathrm{~mm} x$} $100 \mathrm{~mm} \times 6.30 \mathrm{~mm}$ )

$$
\begin{aligned}
\text { Maximum shear } & =\frac{W l}{2}=41.79 \mathrm{kN} / \mathrm{m} \\
\text { Maximum average shear stress } & =\frac{V}{2 b d}=26.53 \mathrm{~N} / \mathrm{mm}^{2}
\end{aligned}
$$

\subsubsection{Allowable stresses in web of beam}

Shear stresses in webs - The maximum average shear stresses $(\mathrm{Fv})$, on the gross area of a flat web shall not exceed (0.4 x fy)

$$
\begin{gathered}
\text { For } \frac{h}{t}<\frac{1425}{\sqrt{ } f y} \\
\mathrm{Fv}=\frac{1275 \sqrt{ } f y}{\frac{h}{t}}=195.2 \mathrm{~N} / \mathrm{mm}^{2} \\
\frac{h}{t}=78 \\
\frac{4590}{\sqrt{f y}}=38.65 \\
\mathrm{FV}=195.2 \mathrm{~N} / \mathrm{mm}^{2}>26.53
\end{gathered}
$$

$\mathrm{N} / \mathrm{mm}^{2}$ Hence Safe in shear

3.3.6 Combined bending and shear stress in webs: $f b^{\prime}{ }^{\prime}=$ $\frac{3636000}{\left(\frac{h}{t}\right) 2}=607.56 \mathrm{~N} / \mathrm{mm}^{2}$

3.3.7 Bending and shear stress in webs: $f b w=\frac{3656000}{\left(\frac{h}{t}\right) 2}=$ $6109.04 \mathrm{~N} / \mathrm{mm}^{2}$

$6109.04 \mathrm{~N} / \mathrm{mm}^{2} .>607.56 \mathrm{~N} / \mathrm{mm}^{2}$ hence working stress method is uneconomical in bending stress

\subsubsection{Check for deflection of built up channel section} $(250 \mathrm{~mm} \times 100 \mathrm{~mm} \times 6.30 \mathrm{~mm})$ in working stress method (IS)

The actual deflection $(\Delta)$ and Permissible deflection is given in table 6.

$$
\begin{aligned}
& \text { Actual deflection }(\Delta)=\frac{5 W 1^{4}}{384 E I} \\
& \text { Permissible deflection }=\frac{\text { span }}{325}
\end{aligned}
$$

Table 6. Deflection

\begin{tabular}{|c|c|c|}
\hline $\begin{array}{l}\text { Effectivelength } \\
(\mathrm{mm})\end{array}$ & $\begin{array}{l}\text { Actual } \\
\text { Deflectio } \\
\mathrm{n}(\Delta) \\
(\mathrm{mm})\end{array}$ & $\begin{array}{l}\text { Permissibl } \\
\text { deflection } \\
(\Delta)(\mathrm{mm})\end{array}$ \\
\hline 1000 & 0.293 & 3.07 \\
\hline 2000 & 4.70 & 6.15 \\
\hline 3000 & 23.82 & 9.230 \\
\hline 4000 & 75.29 & 12.30 \\
\hline 5000 & 183.82 & 15.38 \\
\hline
\end{tabular}

\subsection{Theoretical Investigations of Built Up Channel}

Section $(250 \mathrm{~mm} \times 100 \mathrm{~mm} \times 6.30 \mathrm{~mm})$ using Euro

\section{Code Method}

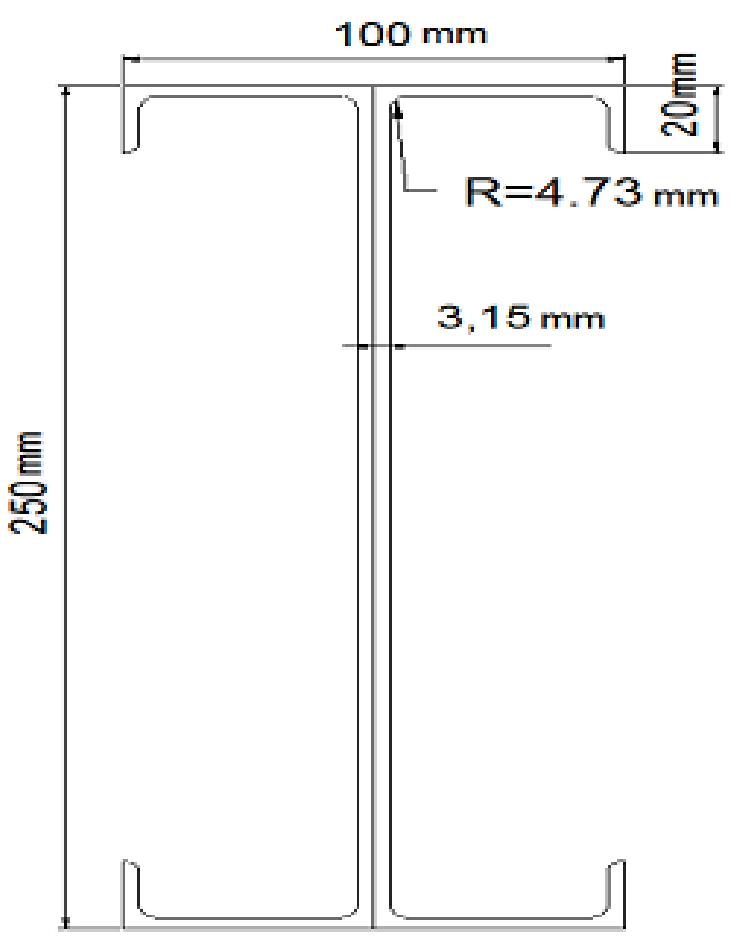

3.4.1 Load caring capacity (p) of channel section ( $250 \mathrm{~mm} \times 100 \mathrm{~mm} \times 6.30 \mathrm{~mm}$ )

Where,

$$
\mathbf{q}_{\mathrm{d}}=\gamma_{\mathrm{u}} \times \mathbf{q}_{\mathrm{u}}+\gamma_{\mathrm{q}} \times \mathbf{q}_{\mathrm{s}}
$$

$$
\begin{aligned}
\mathrm{q}_{\mathrm{d}} & =\text { total dead load } \\
\gamma_{\mathrm{u}}, \gamma_{\mathrm{q}} & =\text { partial safety factor } \\
\mathrm{q}_{\mathrm{u}} & =\text { self weight of beam } \\
\mathrm{q}_{\mathrm{s}} & =\text { span length } \\
\mathbf{q}_{\mathbf{d}} & =\mathbf{1 . 3 5} \times \mathbf{8 . 9 7}+1.50 \times \mathbf{3}=\mathbf{1 8 . 5 3} \mathbf{~} \mathbf{N} / \mathbf{m}
\end{aligned}
$$

3.3.3 Moment of resistance of built up channel section ( $250 \mathrm{~mm} \times 100 \mathrm{~mm} \times 6.30 \mathrm{~mm})$

Moment of resistance $(\mathrm{MR})=$ fy $\mathrm{x} \mathrm{Zxx} / \gamma_{\mathrm{mo}}$ Moment of resistance $(\mathrm{MR})=11.34 \times 10^{6} \mathrm{Nmm}$

\section{EXPERIMENTAL PROCEDURE}

Overall three codes were designed and comparison of all the internal force, and hence, to evaluate the co-existing moments and shear forces at the critical cross-section with same configuration area by keeping all other parameters constant. The working stress method calculated using Indian Standard code IS 801-1975 recommended. The theoretical results the working stress method, the built up channel section the load caring capacity, moment resistance and deflection is $41.79 \%, 35.12 \%$ and $33.40 \%$ lower value compare than the limit state method built up channel section and $77.44 \%$ of load caring capacity is higher compare than the Euro codes. Also $54.03 \%$ of moment resistance is lower than the Euro codes and $77.29 \%$ of deflection is less 
compare than the Euro codes. Slenderness ratio same for all the codes. Allowable stress same for all condition. Euro code provides low value of deflection compare to Indian codes. The theoretical investigations of code of practice given figure below.

4.1 Theoretical Investigations of Built Up Channel Section (250mm x $100 \mathrm{~mm} \times 6.30 \mathrm{~mm})$ the code of Practice, Load Caring Capacity given below

\section{Load Carring Capacity}

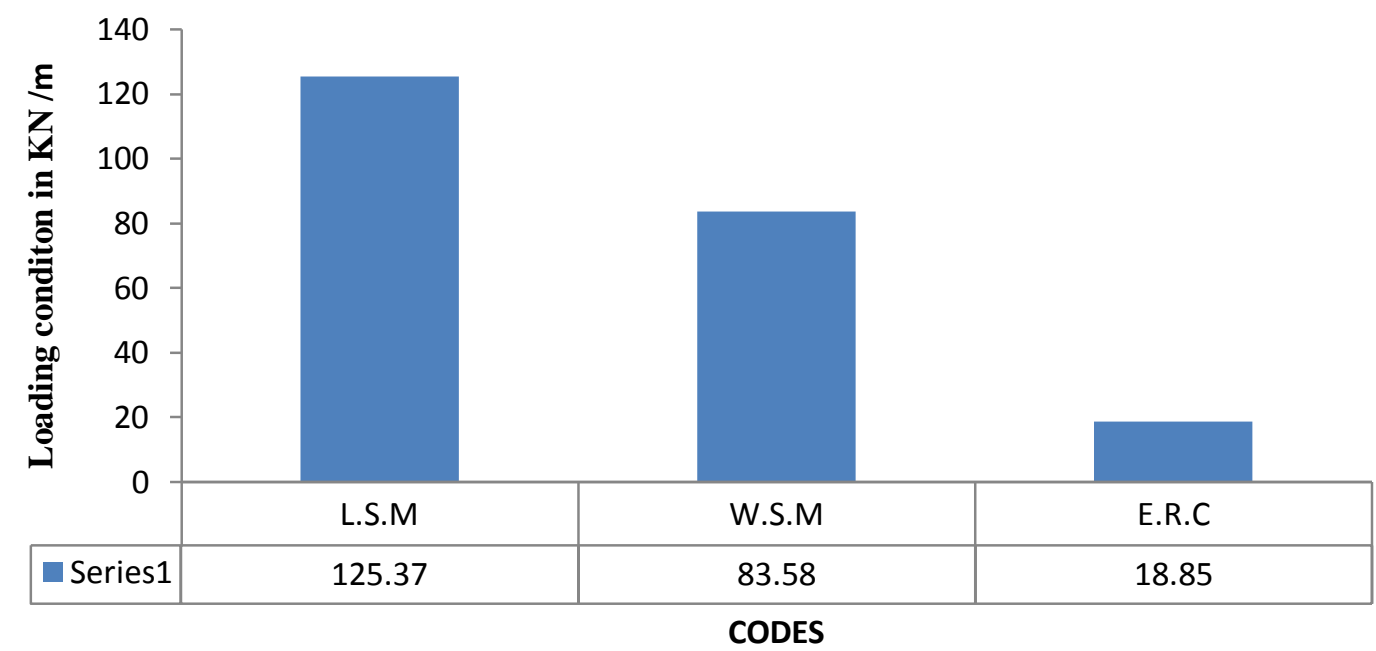

Fig.1 comparison of code of practice theoretical design value load caring capacity of built up channel section

The code of pratice of load caring capacity SI method (limit state design ) is more then the other two methods

4.2 Theoretical Investigations of Built Up Channel Section (250mm x $100 \mathrm{~mm} \times 6.30 \mathrm{~mm})$ the Code of Practice, Moment of Resistance given below

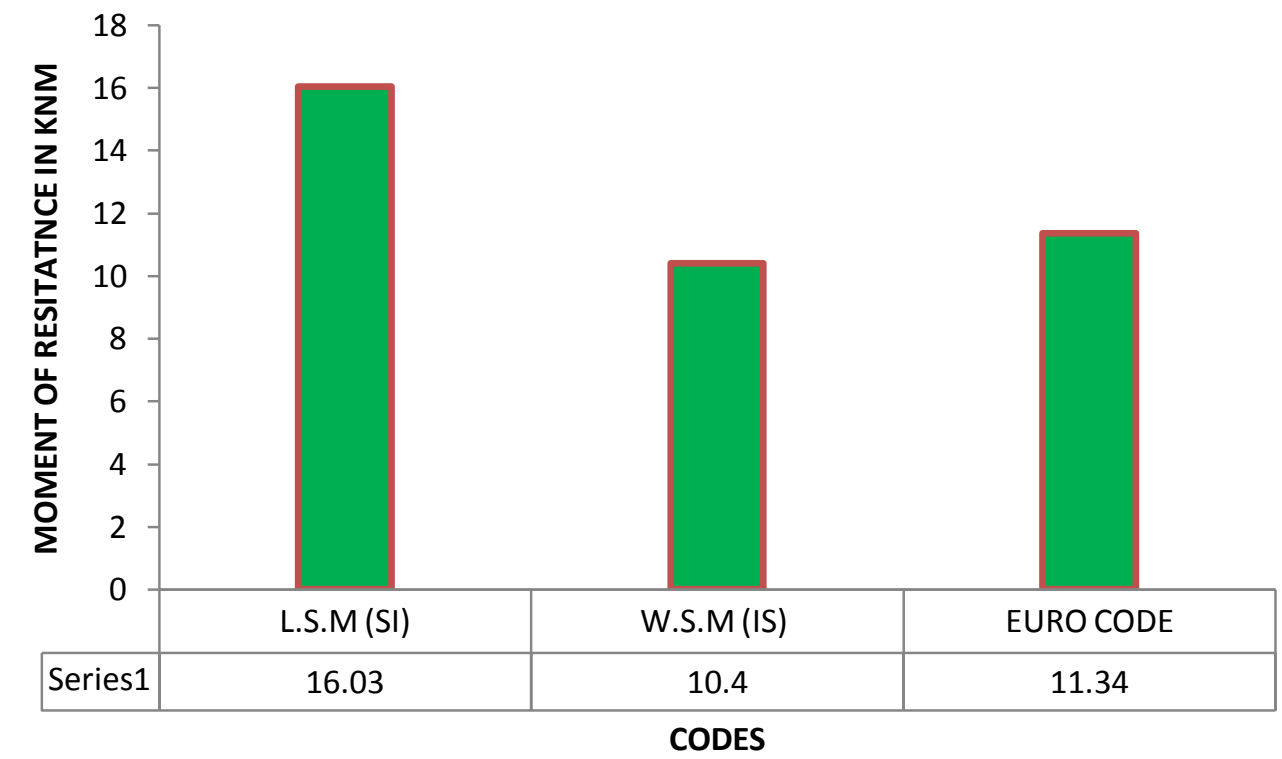

Fig .2 comparison of code of practice theoretical design value moment of resistance of built up channel section

SI method is higher moment of resistance compare to other two indian method methods 
4.3 Theoretical Investigations of Built Up Channel Section (250mm x 100mm x6.30mm) the Code of Practice, Deflection given below

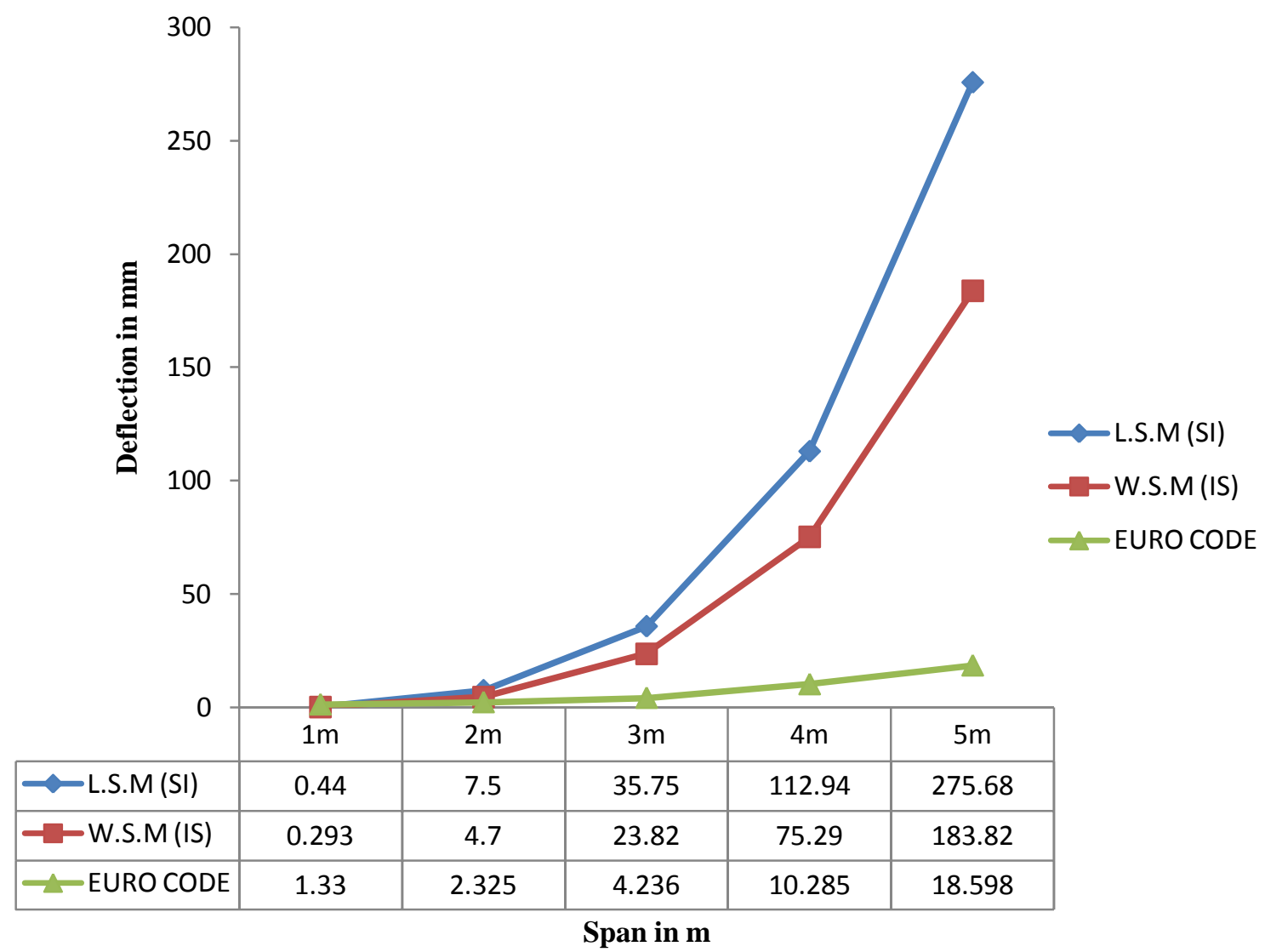

Fig.3 comparison of code of practice theoretical design value deflection of built up channel section

Euro code is lower deflection compare to other two indian method methods

4.4 Theoretical Investigations of Built Up Channel Section (250mm x 100mm x6.30mm) the Code of Practice, Bending Stress given below

Bending stress in Web in N/mm²

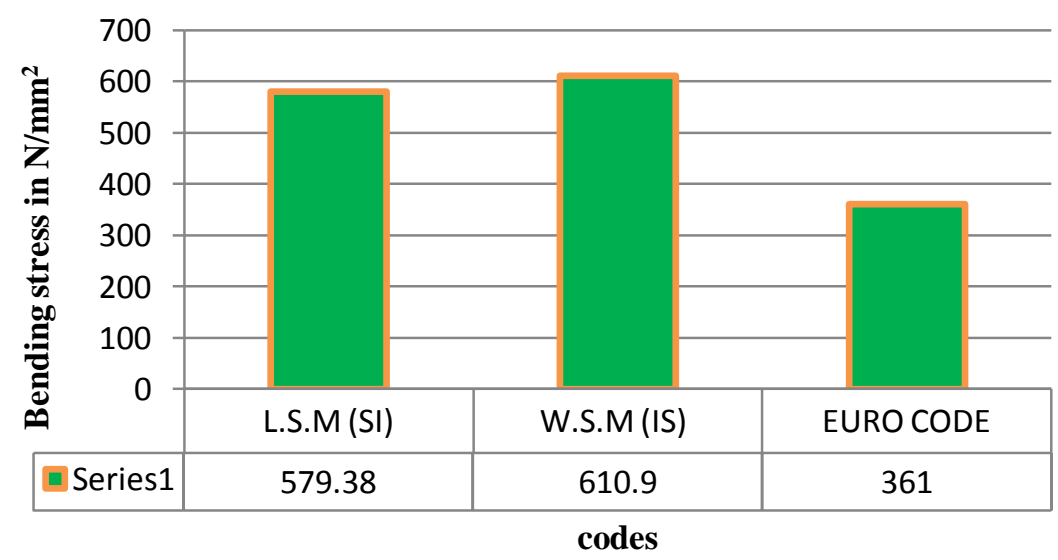

Fig .4 comparison of code of practice theoretical design value bending stress in web built up channel section Euro code is lower bending stress compare to other two indian method methods 
4.5 Theoretical Investigations of Built Up Channel Section (250mm x 100mm x6.30mm) the Code of Practice, Shear Stress in Web given below

\section{Shear Stress in Web in N/mm²}

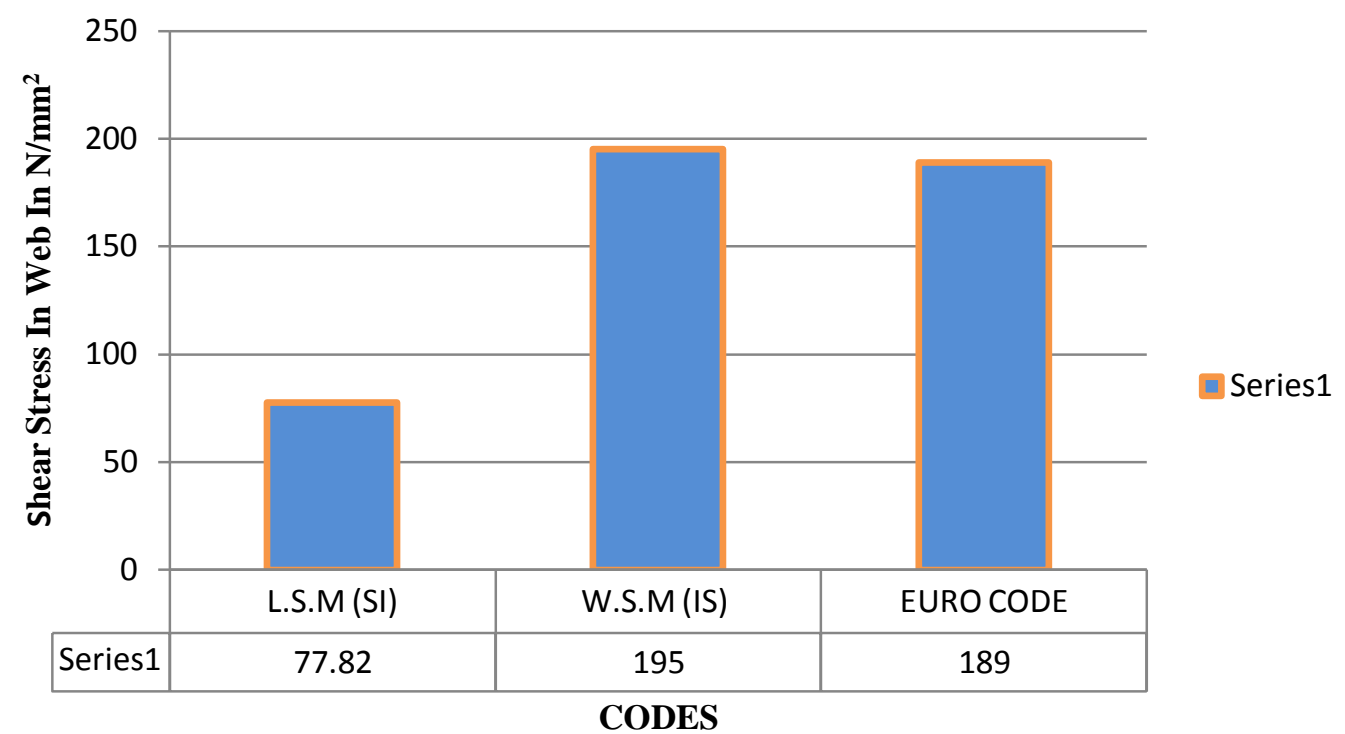

Fig .5 comparison of code of practice theoretical design value shear stress in web built up channel section

SI method (limit state design) is lower bending stress compare to other two method methods

\section{CONCLUSION}

The theoretical results the working stress method, the built up channel section the load caring capacity, moment resistance and deflection is $41.79 \%, 35.12 \%$ and $33.40 \%$ lower value compare than the limit state method built up channel section and $77.44 \%$ of load caring capacity is higher compare than the Euro codes \& $54.03 \%$ of moment resistance is lower than the Euro codes and $77.29 \%$ of deflection is less compare than the Euro codes. Slenderness ratio same for all the codes. Allowable stress same for all condition. Euro code provides low value of deflection compare to Indian codes. The theoretical investigations of code of practice given figure below. The studies reveal that the theoretical investigations limit state methods (SI method) have high bending strength, high load caring capacity, maximum deflection and minimum local buckling\& distortional buckling compare to the other codes.

\section{REFERENCES}

[1] A Jayaraman ${ }^{1}$ V Senthilkumar ${ }^{2} \quad$ S Athibaranan ${ }^{3}$ (2014) "Behaviour and Design of Light gauge Cold Formed Steel Flexural Members (Comparison of Channel and Built up Channel Section)"

[2] S.A.Kakade, B.A.Bhandarkar, S.K. Sonar, A.D.Samare " Study of various design methods for cold - formed light gauge steel sections for compresive strength" International Journal of
Research in Engineering and Technology eISSN: 2319-1163 | pISSN: 2321-7308

[3] M. Meiyalagan , M.Anbarasu and Dr.S.Sukumar.(2010) "Investigation on Cold formed C section Long Column with Intermediate Stiffener \& Corner Lips - Under Axial Compression." International journal of applied engineering research, dindigul, Volume 1, No1, 2010

[4] V.M.Vaghe, S.L.Belgaonkar, A.S.Kharade and A.S.Bhosale ( 2013) "Experimental Study on Connections, By Using Light Gauge Channel Sections and Packing Plates/Stiffener Plate at the Joints.'International Journal of Engineering and Innovative Technology (IJEIT) Volume 2, Issue 7, January 2013.

[5] Sunil. M.Hardwani, A.V.Patil (2012) "Study, test and designing of cold formed section as per AISI code." Int. Journal of Applied Sciences and Engineering Research, Vol. 1, Issue 3, 2012.

[6] P. P. Desai and M. R. Shiyekar (2014) "Limit Strength Prediction of Light Gauge Steel I Section by Finite Element Method.” Int. Journal of Engineering Research and Applications, ISSN: 2248-9622, Vol. 4, Issue 7(Version 4), July 2014, pp.111-114 (2014)

[7] I.S. 801: 1975, "Indian Standard Code of Practice for Use of Cold-Formed Light Gauge Steel Structural Members in General Building Construction", Bureau of Indian Standards, New Delhi. India. 
[8] I.S. 811: 1987, "Indian Standard Specification for Cold- Formed Light Gauge Structural Steel Sections", Bureau of Indian Standards, New Delhi. India.

[9] M. R. Shiyekar, "Limit State Design in structural steel" 2010, PHI Learning Private Limited, New Delhi. 